\title{
DEVELOPMENT OF SHARIA BANKING AND ITS CONTRIBUTIONS FOR THE DEVELOPMENT OF NATIONAL BANKING
}

\author{
Thoriqoh Nashrullah Fitriyah \\ Doctoral Student of Islamic Law Study Program Concentration on Sharia Economics \\ UIN Sunan Gunung Djati, Bandung, Indonesia \\ Email: thoriqohnashrullah75@gmail.com
}

\begin{abstract}
The development and growth of shari'a banks after more than two decades in Indonesia is very spectacular, so that spurred the level of economic growth, but if it is related to the substance of the objectives of sharia bank establishment is the alleviation of poverty and unemployment, it will even increase. Based on data from research studies examining, the contribution of Islamic banking to the development of national law, namely by the existence of people who behave economically in sharia and business behavior of Muslim entrepreneurs are included in the targets of the Islamic economic movement in Indonesia. Even though it looks rather slow, the non-financial side of this economic activity is also growing.
\end{abstract}

Keywords: sharia banking, national banking musharaka, mudaraba

\section{A. INTRODUCTION}

Sharia banking in June 2018 showed positive growth and improved intermediation with increased assets, disbursed financing, and third-party funds which were higher than the same period the previous year (Setyowati, 2019). The performance of Islamic banks in June 2018 generally improved compared to the end of 2017 as indicated by the main financial ratios, both in terms of liquidity, efficiency, profitability, and capital, which showed improvement (IMF Asia and Pacific, 2018).

Table-1

Sharia Banking Growth

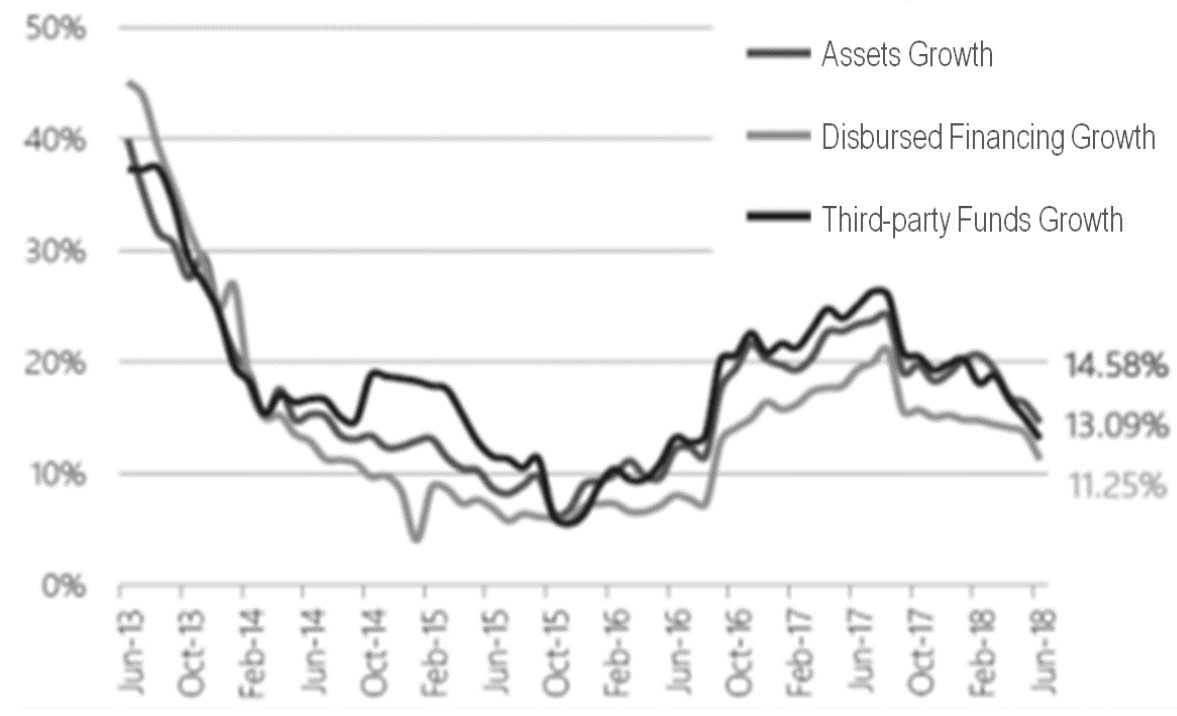

Source: tracking results, processed 
While, assets-based provinces in Indonesia can be seen in the following table:

Table-2

\section{Assets Based on Provinces}

\begin{tabular}{|l|lc|}
\hline 1 & DKI JAKARTA & $56,60 \%$ \\
\cline { 1 - 1 } 2 & JAWA BARAT & $8,58 \%$ \\
\hline 3 & JAWA TIMUR & $6,07 \%$ \\
\hline 4 & $\begin{array}{l}\text { NANGROE ACEH } \\
\text { DARUSSALAM }\end{array}$ & $5,21 \%$ \\
\hline 5 & JAWA TENGAH & $4,36 \%$ \\
\hline
\end{tabular}

\begin{tabular}{|c|c|c|}
\hline 6 & SUMATERA UTARA & $2,55 \%$ \\
\hline 7 & BANTEN & $2,35 \%$ \\
\hline 8 & $\begin{array}{l}\text { SUMATERA } \\
\text { SELATAN }\end{array}$ & $1,51 \%$ \\
\hline 9 & $\begin{array}{l}\text { SULAWESI } \\
\text { SELATAN }\end{array}$ & $1,32 \%$ \\
\hline 1 & $\begin{array}{l}\text { KALIMANTAN } \\
\text { TIMUR }\end{array}$ & $1,31 \%$ \\
\hline
\end{tabular}

Source: tracking results, processed

However, on the other hand, people's expectations (Lone \& Ahmad, 2017) of the vital role of Islamic banking (Yuniarti, 2017) in order to participate in helping the growth as well as the development of the level of welfare of the Indonesian people (Saputro et al., 2018). Until now, it assessed by many Islamic banking experts or Islamic economics themselves are still far from expectations, even blunt, given the banking behavior that it runs not much different from conventional banking (Elsa et al., 2018, pp. 2008-2016), even considered more 'detrimental' to Muslims themselves (Raz, 2019).

According to Usman Kartadijaya, sharia banking is currently only more prominent in the 'clothes' aspect, but there are still many banking principles that are far from the provisions of sharia itself. (Kartadijaya, 2011 : 12). So do not be blamed if the economy of Muslims in Indonesia itself, as if proceeding without convincing Islamic banking encouragement (M. D. Sari et al., 2016), which in the end the poverty rate of Muslims in this country was allegedly even increasing (M. Anton Athoillah, 2017; Mulyadi \& Athoillah, 2017; Rosadi et al., 2018; Rosadi \& Athoillah, 2015; Samsudin \& Athoillah, 2017).

Based on the description above, the authors argue that the problem of the Islamic banking system in developing national legal system development is very important to be studied from the perspective of Islamic morality as the soul of Pancasila, Islamic economic law and its existence in the laws and regulations in Indonesia and the views of the scholars.

\section{B. METHOD}

The approach in this study is qualitative and historical. This qualitative data is based on the content or quality of facts, such as data and explanations that are broken down based on books, newspapers and articles collected by writers relating to the Islamic banking legal system which are then analyzed in order to answer existing problems. While historical data is based on past experience that fully illustrates the whole truth of events or facts that are based on the activity of evaluating an object such as past events or figures viewed from the standpoint of today's standards and culture. What is meant by historical data here are data relating to the development of Sharia Bank law in the country of Indonesia. 


\section{RESULT AND DISCUSSION}

The desire of Indonesian Muslims to have a bank operating in accordance with the principles of Islamic law has long been conceived by Indonesian Muslim figures and scholars (Darsono et al., 2018). The idea of establishing a bank that is in line with the principles of Islamic economics has emerged since 1930. In 1937, K.H. Mansur, Chairperson of PP Muhammadiyah in the period 1937-1944, expressed his opinion on the prohibition of using conventional banking services for Muslims. At that time, he had raised the idea of establishing an Islamic bank in Indonesia (Bisar, 2009) .

Since the beginning of the 1970s, Muslims in various countries have sought to establish Islamic banks (Saeed, 1999). The aim, in general, is to promote and develop the application of Islamic sharia principles and traditions in financial and banking transactions and other related businesses (Baydoun et al., 2018; Burhanudin, 2018; Liswardi, 2018; Nurholis, 2019, 2019; Sholihin, 2018; Wahyuni, 2018). The main principles adopted by the Islamic Bank are: First, the prohibition of usury (interest) in various forms of transactions (Ismal, 2013; Syah \& Kharismasyah, 2018). Second, running a business and trading activities based on the acquisition of legitimate profits according to sharia (Fauzin, 2018; Mu'minah, 2018; Najakh et al., 2018; Venardos, 2006). Third, give zakah (Zainur Arifin, 2009; M Anton Athoillah \& Al-Hakim, 2013; Haniefah \& Faozan, 2018; Syafiq, 2016).

In Indonesia, the role of government is very important (Hefner, 2003). The role of prominent figures is also important, such as former President Soeharto, ICMI General Chairperson, B.J. Habibie or banking figures such as Rahmat Saleh, Minister of BI Governor (Maurer, 2008). It is this political factor that is able to attract investors from conglomerates, SOEs and social foundations. With the influence of former President Soeharto thousands of share buyers could be mobilized to sell 13,529,964 shares of BMl (Muhammad, 2004).

In 1992 the legal basis used was changed to Law No. 7 of 1992 concerning banking (only know the profit sharing bank, Dual Banking System) (Sari, n.d. : 3). The first Islamic financial institution established in the form of a Bank was Bank Muamalat Indonesia (BMI), which was in 1992. The emergence of BMI was motivated by the recommendation of a cleric workshop on bank and banking interest that took place in Cisarua, Bogor 19-22 August 1990. The workshop results were discussed more medalam at the National Conference (Munas) IV Majlis Ulama Indonesia (MUI) which took place at the Sahid Jaya Hotel, Jakarta, August 22-25, 1990. Based on the mandate of the National Conference IV MUI a working group was formed to establish a Sharia Bank in Indonesia (Anshori, 2008).

In 1998 there was Law No. 10 of 1998 . Thus, national banking has its own wisdom where the government is opening up banking business activities based on sharia principles. This is to accommodate the aspirations and needs that develop in the community (Antonio, $2004: 22$ ). In 1999 Law No. 23 of 1999 explained that "Bank Indonesia gave authority to regulate Islamic banks. Then, the enactment of Law No. 21 of 2008 concerning Islamic Banking. The legal umbrella can be used by Islamic Banking to balance equality with Conventional Banking in Indonesia (Umam, 2013). Looking at the history of the development of Islamic banking today, more clearly can be observed in the Development of Sharia Banking Milestone in Indonesia since 1990 (Bank Indonesia, 2004).

In terms of the management system, Islamic banking shows a number of interesting aspects because it makes the scheme of equity participation, risk, and profit and loss sharing the basis of its financing (Mulyana, 2018; Permana, 2019; Sudana \& Marlina, 2019). All of these schemes have one important aspect, namely that all transactions must be real, not just financial transactions, 
and all parties involved in the contract must share the risk by using a profit and lost sharing scheme. (Mervyn \& Lativa, 2007). The development of Islamic banking is so rapid, a variety of products and structuring of Islamic banking policies will be seen in the following figure (Bank Indonesia, 2017).

In the future, investment in Islamic financial institutions will need to involve entrepreneurs as investors (Kholid, 2018). This depends on the performance of Islamic financial institutions so far (Fikri, 2018). There are several performances that must be accounted for. First, the profitability of the financial institution. Second, the benefits of financial institutions for the community, especially in business development or welfare improvement. Third, the dependence (access) of the community on the source of funds, which involves the availability of funds (liquidity) in sufficient quantities, the cost of capital to be paid and the ease of service (Salman \& Nawaz, 2018).

The establishment of this Islamic bank was motivated by the desire of the Islamic community to avoid usury in muamalah activities, establish Islamic brotherhood among fellow Muslims and obtain inner and outer welfare through muamalah activities in accordance with religious orders so as to get the blessing of Allah SWT (M Anton Athoillah \& Al-Hakim, 2013). That concept is what makes Islamic banking have more value than conventional banking. This added value is proven to be an effective driving machine for the development of sharia banking, because the added value is also a special attraction for the development of sharia in the eyes of the public. (Sari, n.d. : 2). Although the existence of sharia banking is relatively new in the financial system in Indonesia, sharia banking is growing rapidly and showing impressive performance.

Islam is a religion that governs all aspects of life comprehensively, and is universal in keeping with the dynamics of life (Rafiki \& Wahab, 2014). As a "way of live" Islam sees the close and integral connection between faith and people's lives, politics, law, education, and economy. Islam is not a secular religion that separates religion and social phenomena. In the field of law, Islam is the rule of law for all Muslims without exception. In the context of nationality, Islamic Law is all rules based on the Qur'an and the Sunnah of the Messenger of Allah (Muhammad SAW) on the actions of human beings who are believed and recognized to be valid and binding on all Muslims with the approval of the State, or have become national laws, such as law Islamic jurisprudence in sharia banking has been included in Law No. 21 of 2008 on Shariah Banking.

The acceptance of Islamic law in Indonesia becomes National Law because it is legally formal and normative, Islamic law has become a living law in Indonesian society. As a country with a Muslim population, of course the most relevant law and in accordance with the soul of the nation is a positive law that is in accordance with the religion adopted. In the field of economics, Islam provides guidelines that are perfect, straightforward and firm, both theoretically and actually, Islam requires every Muslim to manifest his teachings in all aspects of life. It is not as complete as the faith of a Muslim if he performs worship every day, but in his daily conduct transactions that deviate from the teachings of Islam (Pratama et al., 2019).

As a universal religion certainly pays attention to the problem of economic development. According to Islam, economic development is multi-dimensional which includes quantitative and qualitative aspects. The goal is not merely the material welfare of the world, but also the happiness of the afterlife (Iqbal, 1990 : 102). God's Word in the Qur'an Surah An-Nisaa 'verse 29: Meaning: 0 you who believe, do not eat one another's goods in a way that is unprofitable, except in the way of Business that is pleasing to you. and do not kill yourself; Verily, Allah is Most Merciful to you. 
The above paragraphs indicate how important it is to be in a business of willingness or agreement with the parties to the transaction, thus avoiding any regret or frustration that may result from hatred, revenge, or murder.

The development of Islamic Banking which began in 1991 continued to experience growth and development until mid-1997, and very significant growth actually occurred since the economic crisis in 1997. This is due to the ability of Islamic Banking in dealing with monetary turmoil marked by very high interest rates, while Banking Sharia is free from negative spread because it is not based on interest (Zainul Arifin, 2000 : 9).

However, the development of Islamic Banking has not been matched by advances in the legal sector in the absence of specific laws elaborating on the specificity of Islamic Banking. It was only after 28 years later since the establishment of the Syariah Bank of the House of Representatives with the Government formed Law No. 21 of 2008 concerning Islamic Banking. It can be said that the Ratification of the Sharia Banking Law by the Parliament on June 17, 2008 and the enactment by President Susilo Bambang Yudoyono on July 16, 2008 was very late. Because, in colonial times alone, the Dutch colonial government had already accommodated some of the aspirations of the Muslim community in the field of Islamic economics, which was reflected in the 1938 usury ordinance on Riba which gave the authority to the judge to cancel an agreement which incriminated either party (article 2 paragraph 14 of the Ordinance Usury 1938) (Himpunan Peraturan Perundang-Undangan Republik Indonesia, Addenda Chogada, n.d. : 1).

The model of implementation of Islamic Law in Islamic Banking is static and develops at the same time. The static policy lies in the principle and fundamental level. Whereas what is meant by the dynamic implementation of Islamic Law is that each of its basic principles is very easy to adapt to various application models in every place and time, so as to create the conditions of Citeris Paribus (Pusat Pengkajian dan Pengembangan Ekonomi Islam (P3EI) UII dan BI, 2008 : 173)

Understanding the Implementation of Islamic Law in Sharia Banking in Indonesia has a high-value urgency, both in the form of principles, laws and application models, so that Islamic Banking is able to catch up with conventional banks in the country and / or existing Islamic banks in this world.

\section{CONCLUSION}

The contribution of Islamic banking to the development of national law, namely the existence of people who behave economically in sharia and business behavior of Muslim entrepreneurs are included in the targets of the Islamic economic movement in Indonesia. Even though it looks rather slow, the non-financial side of this economic activity is also growing. This is marked by increasing public awareness of Islamic economic institutions.

\section{REFERENCES}

Anshori, A. G. (2008). Penerapan Prinsip Syariah Dalam Lembaga Keuangan, Lembaga Pembiayaan dan Perusahaan Pembiayaan. Pustaka Pelajar.

Antonio, S. (2004). Bisnis dan Perbankan Dalam Perspektif Islam. Ekonisia.

Arifin, Zainul. (2000). Memahami Bank Syariah; Lingkup, Peluang, Tantangan dan Prospek (III). Alvabet. 
Arifin, Zainur. (2009). Dasar-dasar Manajemen Bank Syariah. Azkia.

Athoillah, M. Anton. (2017). Zakat untuk Kesejahteraan Bangsa. Media Syari'ah, 16(2), 453-538.

Athoillah, M Anton, \& Al-Hakim, S. (2013). Reinterpreting the Ratio legis of the Prohibition of Usury. Middle-East Journal of Scientific Research, 14(10), 1390-1400. https://doi.org/10.5829/idosi.mejsr.2013.14.10.2187

Athoillah, Mohamad Anton. (2013). Zakat as an Instrument of Eradicating Poverty (Indonesian Case). International Journal of Nusantara Islam, 1(1), 73-85. https://doi.org/10.15575/ijni.v1i1.37

Bank Indonesia. (2004). Cetak Biru Pengembangan Perbankan Syariah Nasional. Bank Indonesia.

Bank Indonesia. (2017). Kebijakan Perbankan Syariah. Bank Indonesia.

Baydoun, N., Sulaiman, M., Willett, R. J., \& Ibrahim, S. (2018). Principles of Islamic Accounting. John Wiley \& Sons.

Bisar, C. (2009). Penyelesaian Sengketa Perbankan Syariah Di Pengadilan Agama dan Mahkamah Syari'ah. Kencana.

Burhanudin, M. (2018). The Application of the Hybrid Contracts Concept to Multipurpose Financing. Journal of Economicate Studies, 2(2), Article 2. https://doi.org/10.32506/joes.v2i2.471

Darsono, D., Astiyah, S., Darwis, A., Sakti, A., \& Suryanti, E. T. (2018). Dynamics of Islamic Finance Products and Contracts in Indonesia (M. S. Antonio, S. R. Zaid, \& F. Sabilar R., Eds.). Tazkia - Bank Indonesia.

Elsa, E., Utami, W., \& Nugroho, L. (2018). A Comparison of Sharia Banks and Conventional Banks in Terms of Efficiency, Asset Quality and Stability in Indonesia for the Period 2008-2016. International Journal of Commerce and Finance, 4(1), 134-149.

Fauzin, A. (2018). Imposition of Sanctions (Ta'zir) and Punitive Damages (Ta'widh) to Customers in Musyarakah Mutanaqishah Contract. Journal of Economicate Studies, 2(1). https://doi.org/10.32506/joes.v2i1.465

Fikri, Y. T. A. (2018). Bargaining Mechanism in Islamic Economic System. International Journal of Nusantara Islam, 6(1), 104-114. https://doi.org/10.15575/ijni.v6i1.4399

Haniefah, F. R., \& Faozan, A. (2018). The Optimization of the Role of Zakat in the Alleviating Poverty in Indonesia. Journal of Economicate Studies, 2(2), Article 2. https://doi.org/10.32506/joes.v2i2.470

Hefner, R. W. (2003). Islamizing Capitalism: On the Founding of Indonesia's First Islamic bank. In A. Salim \& A. Azra (Eds.), Shari'a and Politics in Modern Indonesia. Insitute of Southeast Asian Studies.

Himpunan Peraturan Perundang-undangan Republik Indonesia, Addenda Chogada. (n.d.). PT. Ikhtiar Baru Van Hoeve. 
IMF Asia and Pacific. (2018). Indonesia: 2017 Article Iv Consultation-Press Release; Staff Report; and Statement by the Executive Director for Indonesia. International Monetary Fund. https://public.ebookcentral.proquest.com/choice/publicfullrecord.aspx?p=5301642

Iqbal, M. (1990). Financing Economic Development. Planduk Publication.

Ismal, R. (2013). Islamic Banking in Indonesia: New Perspectives on Monetary and Financial Issues. Wiley Singapore.

Kartadijaya, U. (2011). Menyoroti Fenomena Perbankan Syariah di Indonesia. PT.Insan Madani.

Kholid, M. (2018). Sharia Arbitration as an Alternative Settlement of Sharia Banking Disputes. International Journal of Nusantara Islam, 6(1), 73-92. https://doi.org/10.15575/ijni.v6i1.4043

Liswardi, L. (2018). The Application of Contract of Wakalah Bi Al-Ujrah on Letter of Credit Services in Sharia Bank. Journal of Economicate Studies, 2(1), Article 1. https://doi.org/10.32506/joes.v2i1.462

Lone, F. A., \& Ahmad, S. (2017). Islamic Finance: More Expectations and Less Disappointment. Investment Management and Financial Innovations, 14(1), 134-141. https://doi.org/10.21511/imfi.14(1).2017.14

Maurer, B. (2008). Mutual Life, Limited: Islamic Banking, Alternative Currencies, Lateral Reason. Princeton University Press.

Mervyn, \& Lativa. (2007). Perbankan Syariah: Prinsip, Praktik, dan Prospek. Serambi.

Muhammad. (2004). Analisis SWOT Bank Syariah. Ekonisia.

Mulyadi, D., \& Athoillah, M. A. (2017). PRODUCT INNOVATION OF SHARIA FINANCIAL INSTITUTION: THEORY REVIEW. Journal of Economicate Studies, 1(1), 1-8. https://doi.org/10.32506/joes.v1i1.3

Mulyana, D. (2018). Market Structure and Competition Price in Islamic Economics. International Journal of Nusantara Islam, 6(2), 144-153. https://doi.org/10.15575/ijni.v6i2.4401

Mu'minah, M. (2018). The Implementation of ljarah Muntahiya Bittamlik and Mudharabah Products in the Sharia Economic Law Perspective. Journal of Economicate Studies, 2(2), Article 2. https://doi.org/10.32506/joes.v2i2.472

Najakh, A. K., Astogini, D., \& Martini, S. (2018). The Influence of Attitudes, Subjective, Norms, and Behavior Controls on Intention to Choose Islamic Banks with Islamic Religiosity as a Moderating Variable (case Study at Bri Syariah Purwokerto Customers). Journal of Economicate Studies, 2(1). https://doi.org/10.32506/joes.v2i1.464

Nurholis, A. (2019). The Basic Concept of Bayt Al-Māl Wa Al-Tamwīl (bmt) in Developing Community Economy. Journal of Economicate Studies, 3(1), Article 1. https://doi.org/10.32506/joes.v1i1.500

Permana, Y. (2019). Market, Market Mechanism and Price Levels in Islamic Microeconomics Perspective. International Journal of Nusantara Islam, 7(2), 167-175. https://doi.org/10.15575/ijni.v7i2.5804 
Pratama, A. P., Disemadi, H. S., \& Prananingtyas, P. (2019). Existence and Position of Islamic Economic Laws in Indonesia. Legality : Jurnal IImiah Hukum, 27(2), 222-231. https://doi.org/10.22219/jihl.v27i2.10159

Pusat Pengkajian dan Pengembangan Ekonomi Islam (P3EI) UII dan BI. (2008). Ekonomi Islam. RajaGrafindo Persada.

Rafiki, A., \& Wahab, K. A. (2014). Islamic Values and Principles in the Organization: A Review of Literature. Asian Social Science, 10(9), p1. https://doi.org/10.5539/ass.v10n9p1

Raz, T. J. (2019, November 25). Challenges of Sharia Banking in Indonesia. The Jakarta Post. https://www.thejakartapost.com/academia/2019/11/25/challenges-of-sharia-banking-inindonesia.html

Rosadi, A., \& Athoillah, M. A. (2015). Distribusi zakat di Indonesia: Antara sentralisasi dan desentralisasi. litihad : Jurnal Wacana Hukum Islam dan Kemanusiaan, 15(2), 237-256. https://doi.org/10.18326/ijtihad.v15i2.237-256

Rosadi, A., Effendi, D., \& Busro, B. (2018). The Development of Waqf Management Throught Waqf Act in Indonesia (Note on Republic of Indonesia Act Number 41 of 2004 regarding Waqf). MADANIA: JURNAL KAJIAN KEISLAMAN, 22(1), 1-18. https://doi.org/10.29300/madania.v22i1.881

Saeed, A. (1999). Islamic Banking and Interest: A Study of the Prohibition of Riba and Its Contemporary Interpretation. Brill.

Salman, A., \& Nawaz, H. (2018). Islamic Financial System and Conventional Banking: A Comparison. Arab Economic and Business Journal, 13(2), 155-167. https://doi.org/10.1016/j.aebj.2018.09.003

Samsudin, A. R., \& Athoillah, M. A. (2017). SAVINGS INVESTMENTS IN SHARIA BANKS IN THE PERSPECTIVE OF SHARIAH ECONOMIC LAW (CASE STUDY AT "BANK SYARIAH BUKOPIN"). Journal of Economicate Studies, 1(2), 63-80. https://doi.org/10.32506/joes.v1i2.175

Saputro, A. D., Rois, A. K., \& Bazi, U. A. (2018). Heart Half Implementation Sharia Banking in Indonesia. IKONOMIKA, 3(2), 127-138. https://doi.org/10.24042/febi.v3i2.3258

Sari, M. D., Bahari, Z., \& Hamat, Z. (2016). History of Islamic Bank in Indonesia: Issues Behind Its Establishment. International Journal of Finance and Banking Research, 2(5), 178. https://doi.org/10.11648/j.ijfbr.20160205.13

Sari, T. (n.d.). Strategi Pemasaran dan Peran Perbankan Syariah dalam Perekonomian Indonesia. STEI AUB.

Setyowati, N. (2019). Macroeconomic Determinants of Islamic Banking Products in Indonesia. Economies, 7(2), 53. https://doi.org/10.3390/economies7020053

Sholihin, R. (2018). The Sharia Bank Syndication Financing in the Economic Law Perspective. Journal of Economicate Studies, 2(2), Article 2. https://doi.org/10.32506/joes.v2i2.467 
Sudana, S., \& Marlina, L. (2019). The Influence of Economic Growth, Job Opportunity and People Prosperity on Islamic Banking Growth In Six Provinces in Java Island. International Journal of Nusantara Islam, 7(2), 190-202. https://doi.org/10.15575/ijni.v7i2.6343

Syafiq, A. (2016). Prospek Zakat Dalam Perekonomian Modern. ZISWAF : Jurnal Zakat Dan Wakaf, 1(1), 1-26. https://doi.org/10.21043/ziswaf.v1i1.1530

Syah, T. A., \& Kharismasyah, A. Y. (2018). The Effect of Inflation, Bank Indonesia Rate, Non Performing Financing, and Costs of Operating Expenses to Operating Revenues on Profitability of Sharia Commercial Banks in Indonesia. Journal of Economicate Studies, 2(2), Article 2. https://doi.org/10.32506/joes.v2i2.469

Umam, K. (2013). Manajemen Perbankan Syariah. Pustaka Setia.

Venardos, A. M. (2006). Islamic Banking and Finance in South-East Asia: Its Development and Future. World Scientific.

Wahyuni, S. (2018). Analysis of Cash Buying and Murabahah Financing (case Study on Green Mutiara Housing Tambaksogra PT Graha Perwira Pratama, Kembaran Sub-District, Banyumas Regency). Journal of Economicate Studies, 2(1), Article 1. https://doi.org/10.32506/joes.v2i1.463

Yuniarti, F. R. (2017, January 16). Islamic Banking a Gloomy Industry. The Jakarta Post. https://www.thejakartapost.com/academia/2017/01/16/islamic-banking-a-gloomyindustry.html 